\title{
Covid-19: GP surgeries close for two weeks after staff test positive
}

\author{
Gareth lacobucci
}

The BMJ

The decision to close two general practices in Devon for almost two weeks was taken after practice staff tested positive for the virus that causes covid-19, The BMJ has learnt.

In recent weeks more practices have closed for short periods for precautionary reasons amid fears that the virus could spread. Surgeries in Essex, Hampshire, Cornwall, and Brighton have all had to shut temporarily. ${ }^{1-5}$

The longest closure to date was announced on 4 March when Chelston Hall Surgery and its branch site Barton Surgery in Torquay said that they would be closed until at least 16 March to help "contain the spread" of the virus, ${ }^{6}$ after advice from Public Health England.

NHS England and NHS Improvement said that the decision was taken after staff tested positive for the virus. A spokesperson said, "The practice has closed after two further positive cases of coronavirus were confirmed among staff, meaning that all staff have been advised by Public Health England to self-isolate for 14 days."

The practice, which has around 20000 patients at its two sites, has told patients that they can access care and medications online or from other local practices while their surgeries are temporarily closed. In a statement on its website it said that it was working with local providers to ensure that "all patients registered with the practice continue to access local GP, community pharmacy and health services during this period."

Steve Harris, a local GP and strategic clinical lead for primary care at Devon Clinical Commissioning Group, said, "GP practices only close as an absolute last resort-in this instance, following advice from Public Health England to protect patients against the spread of coronavirus. Patients will always be given access to alternative arrangements as soon as possible when a GP practice has to close."
Richard Vautrey, chair of the BMA's General Practitioners Committee, emphasised that practices would not face contractual repercussions if they closed because of such extenuating circumstances. He said, "Practices must be allowed to make decisions locally, based on the latest public health guidance, that guarantee the safety of both their patients and staff.

"The current contract means practices choose the hours they operate in line with the reasonable needs of their patients and based on what is appropriate for the local population. So, while rare at this stage, if the practice feels it is necessary to close for cleaning to reduce the risk of covid-19 infection, there can be no contractual repercussions."

Vautrey said that practices should notify their clinical commissioning group and their patients if they had to close, so that patients could continue to access services. But he added, "We must stress, however, that people who are concerned about covid-19 should not be going into their GP practice or other healthcare setting anyway_rather they should contact NHS 111 and wait further advice - and therefore the need for practices to close should be minimal at present."

Fullwell Cross Medical Centre. 4th March 2020-coronavirus update. Feb 2020. https:// www.fullwellcrosscentre.co.uk

2 Mid Essex Clinical Commissioning Group. Update about Mount Chambers Surgery. Feb 2020. https://midessexccg.nhs.uk/news/1111-update-about-mount-chambers-surgery.

3 Nixon A. GP surgery closed due to worries over the coronavirus. Romsey Advertiser. 27 Feb. https://www.romseyadvertiser.co.uk/news/18265690.gp-surgery-closed-due-worriescoronavirus.

4 Coronavirus: Cornish GP surgery closed for clean. Pirate FM. Feb 2020. https://www. piratefm.co.uk/news/latest-news/3051163/coronavirus-cornish-gp-surgery-closed-forclean.

5 Mahase E. Coronavirus: online GP bookings should be stopped because of safety risks, warns BMA. BMJ 2020:368:m611. 10.1136/bmj.m611 32054601

6 Chelston Hall Surgery. Important notice to all patients. https://www.chelstonhall.co.uk/ notice-board-sp-2126286822/current-notices.

Published by the BMJ Publishing Group Limited. For permission to use (where not already granted under a licence) please go to http://group.bmj.com/group/rights-licensing/ permissions 